\title{
8: $104380276-104414270$
}

National Cancer Institute

\section{Source}

National Cancer Institute. 8: 104380276-104414270. NCI Thesaurus. Code C42349.

Physical location of FZD6_Gene 